\title{
CD4 T Follicular Helper Cells and HIV Infection: Friends or Enemies?
}

\author{
Félicien Moukambi', Vasco Rodrigues², Yasmina Fortier², Henintsoa Rabezanahary', \\ Chloé Borde ${ }^{2}$, Bernard Krust ${ }^{2}$, Guadalupe Andreani', Ricardo Silvestre ${ }^{3,4}$, \\ Constantinos Petrovas ${ }^{5}$, Mireille Laforge $^{2}$ and Jérôme Estaquier ${ }^{1,2 *}$
}

${ }^{1}$ Centre Hospitalier Universitaire (CHU) de Québec Research Center, Faculty of Medicine, Laval University, Québec, QC, Canada, ${ }^{2}$ CNRS FR3636, Faculty of Medecine des Saint-Pères, Paris Descartes University, Paris, France, ${ }^{3}$ School of Health Sciences, Life and Health Sciences Research Institute (ICVS), University of Minho, Braga, Portugal, ${ }^{4}$ ICVS/3B's-PT Government Associate Laboratory, Braga/Guimarães, Portugal, ${ }^{5}$ Tissue Analysis Core, Vaccine Research Center, National Institute of Allergy and Infectious Diseases, National Institutes of Health, Bethesda, MD, USA

OPEN ACCESS

Edited by:

Scott Hale,

University of Utah, USA

Reviewed by:

Guido Ferrari,

Duke University, USA

Marina Caskey,

The Rockefeller University, USA

*Correspondence:

Jérôme Estaquier

estaquier@yahoo.fr

Specialty section:

This article was submitted

to HIV and AIDS,

a section of the journal

Frontiers in Immunology

Received: 21 September 2016

Accepted: 26 January 2017

Published: 20 February 2017

Citation:

Moukambi F, Rodrigues V, Fortier $Y$, Rabezanahary H, Borde C, Krust B, Andreani $G$, Silvestre $R$, Petrovas $C$, Laforge M and Estaquier J (2017) CD4 T Follicular Helper Cells and HIV Infection: Friends or Enemies?

Front. Immunol. 8:135. doi: 10.3389/fimmu.2017.00135
Follicular T helper (Tfh) cells, a subset of CD4 T lymphocytes, are essential for memory $B$ cell activation, survival, and differentiation and assist B cells in the production of antigen-specific antibodies. Work performed in recent years pointed out the importance of Tfh cells in the context of HIV and SIV infections. The importance of tissue distribution of Tfh is also an important point since their frequency differs between peripheral blood and lymph nodes compared to the spleen, the primary organ for B cell activation, and differentiation. Our recent observations indicated an early and profound loss of splenic Tfh cells. The role of transcriptional activator and repressor factors that control Tfh differentiation is also discussed in the context of HIV/SIV infection. Because Tfh cells are important for B cell differentiation and antibody production, accelerating the Tfh responses early during HIV/SIV infection could be promising as novel immunotherapeutic approach or alternative vaccine strategies. However, because Tfh cells are infected during the HIV/SIV infection and represent a reservoir, this may interfere with HIV vaccine strategy. Thus, Tfh represent the good and bad guys during HIV infection.

Keywords: AIDS, Tfh, CD4, B cell, vaccine, pathogen, SIV, reservoir

Adaptive immunity against pathogens originates with the expansion of antigen-specific $\mathrm{T}$ lymphocytes in secondary lymphoid organs. T cells are a heterogeneous population (1). Based on an array of cell surface markers, distinct subsets have been discriminated including naive, central memory $\left(\mathrm{T}_{\mathrm{CM}}\right)$, effector memory $\left(\mathrm{T}_{\mathrm{EM}}\right)$, and terminally differentiated $\left(\mathrm{T}_{\mathrm{DT}}\right) \mathrm{T}$ cells $(2)$. The function of $\mathrm{T}_{\mathrm{EM}} \mathrm{T}$ cells is dependent not only on the production of cytokines, but also on the expression of a particular set of chemokine receptors that determine in a combinatorial fashion, the steps of extravasation and positioning in different tissue microenvironments (3-5). The discovery of follicular T helper (Tfh) cells dates back to the early 1990s, during a key period coincident with the acknowledgment of the crucial importance of chemokines in immunology. CXCL13 or B cell-attracting chemokine 1 (BCA-1) $(6,7)$ is the selective chemokine ligand for CXC chemokine receptor 5 (CXCR5, originally named MDR15/BLR1); the phenotypic marker used to characterize Tfh cells in early studies $(8,9)$.

Circulating memory CD4 $\mathrm{T}$ cells bearing the phenotype of Tfh cells have been termed "circulating Tfh" or "peripheral Tfh." While some assume that peripheral Tfh cells are the bona fide circulating counterparts of lymphoid tissue Tfh cells $(10,11)$, such notion remains controversial (12) as revealed by RNA sequencing (13) and levels of programmed death molecule-1 (PD-1) $(14,15)$ in circulating Tfh cells compared to those in lymphoid tissues (16). Tfh cells are relatively scarce in peripheral blood 
of healthy individuals. Therefore, it is of crucial importance to analyze Tfh cells in deep tissues.

Because of their ability to support the generation of strong antibody responses, memory Tfh cells are the subject of intense investigation aimed at harnessing this property for novel vaccination approaches as well as immune therapies for infectious diseases and cancer. Growing researches have been dedicated to the characterization of Tfh dynamics during microbe infections, particularly during HIV. This review summarizes recent advances in this growing field.

\section{DYNAMICS OF Tfh CELLS DURING AIDS}

Lymphopenia is a hallmark of the progression to AIDS. As infection progresses, CD4 T cell count progressively declines. The excessive induction of apoptosis and immune activation has been proposed as major mechanisms responsible for the CD4 $\mathrm{T}$ cell depletion $(17,18)$. Studies performed in pathogenic and non-pathogenic lentiviral infections in non-human primate models have further suggested a correlation between the pathology and the levels of CD4 T cells apoptosis and immune activation (19-21). The extent of T cells apoptosis in lymph nodes (LNs) during primary infection predicts disease progression (22, 23) and increased apoptosis is also observed in the intestinal lamina propria $(24,25)$. In particular, memory $\mathrm{CD}^{+} \mathrm{T}$ cells are rapidly depleted in lymphoid tissues $(26,27)$ and are more prone to undergo apoptosis $(23,28)$.

As a subset of memory CD4 T cells, Tfh cells were expected to undergo progressive depletion during AIDS. However, Tfh frequencies are increased in the blood (29), and LNs of chronically infected individuals (30). This frequency increases among the pool of memory CD4 T cells in SIV-infected monkeys (31-33). On the contrary, Boswell et al. (13) showed a loss of Tfh cells during HIV infection. Petrovas et al. (34) have initially reported that half of the chronically SIV-infected rhesus macaques (RM) had increased numbers of LN Tfh cells, which are associated with preserved lymphoid architecture and lower accumulation of naive CD4 T cells, a hallmark of non-progression to AIDS. Two recent reports also indicated that the numbers of Tfh are higher in LNs of non-progressor compared to progressor SIV-infected RMs $(35,36)$. While the spleen contains the majority of Tfh cells, their dynamics in this compartment was still missing. We recently demonstrated an early depletion of splenic Tfh cells after SIV infection of RMs (16). This depletion persists in monkeys progressing faster to AIDS. These results underline the critical impact of tissue compartmentalization on Tfh cell dynamics during AIDS. Therefore, assuming that the dynamics of circulating Tfh reflects the dynamics of their lymphoid tissue counterparts should be taken with caution and merits to be reevaluated.

\section{TRANSCRIPTIONAL FACTORS AND ABNORMAL DIFFERENTIATION OF Tfh CELLS DURING AIDS}

Bcl-6 promotes the Tfh transcriptional program, at least in part by suppressing the expression of the transcriptional regulators such as T-bet (Th1) (37), ROR $\gamma t$ (Th17) (38), GATA3 (Th2) (39), and Blimp-1 (40-42). Bcl-6 and Blimp-1 are mutually antagonistic, and the balance between the expression of these two factors is a critical element in determining the fate of Tfh cells. Nevertheless, others have proposed an alternative, STAT3-independent pathway, for Tfh cell development (43). In addition to Bcl-6, it has been shown that Maf plays an important role in the differentiation and/or function of Tfh cells $(44,45)$. Among the transcriptional repressors, Krüppel-like factor 2 (KLF2) restrains Tfh cell differentiation by inhibiting CXCR5 and Bcl-6 expression $(46,47)$ (Figure 1A). KLF2 is one of the genes targeted by Foxo1, which has been also shown to negatively regulate the differentiation of Tfh cells through at least the involvement of the E3 ubiquitin ligase Itch $(48,49)$. KLF2 as well as Foxo1 regulate the expression of CD62L $(50,51)$, which may have an impact on T cell redistribution. Whereas in uninfected mice, most of Tfh cells are $\mathrm{T}_{\mathrm{EM}}$ cells (CD45RA ${ }^{-} \mathrm{CD}^{2} 2 \mathrm{~L}^{-}$), they exhibit a central $\mathrm{T}_{\mathrm{EM}}$ phenotype $\left(\mathrm{CD} 45 \mathrm{RA}^{-} \mathrm{CD} 62 \mathrm{~L}^{+}\right)$after lymphocytic choriomeningitis virus infection (12). Our results demonstrated similar commutation of Tfh splenocytes during SIV infection (16). Because $\mathrm{T}_{\mathrm{CM}}$ cells are less prone to die than $\mathrm{T}_{\mathrm{EM}} \mathrm{CD} 4 \mathrm{~T}$ cells of HIV- and SIV-infected individuals $(23,28,52-54)$, the observation that splenic Tfh cells of SIV-infected RMs present a switch toward $\mathrm{T}_{\mathrm{CM}}$ phenotype may reconcile the apparently contradictory observations that the frequency of Tfh cells increases among the pool of memory CD4 $\mathrm{T}$ cells, whereas total Tfh cell numbers decreased. Our results have also indicated that Tfh transiently expressed higher levels of Bcl-6 and Maf, whereas Foxo1 and KLF2 are increased in Tfh cells of SIV-infected RMs concomitantly with higher levels of CD62L (16) (Figures 1B and 2). However, the list of transcriptional factors regulating Tfh cell differentiation is growing, which includes the basic leucine zipper transcriptional ATF-like (BATF), interferon regulatory factor 4 , achaete-scute complex homolog 2 (55), NFATC1 (56), STAT1 (57), TCF1 (58-61), and Bob1 (62), and merit to be further analyzed in the context of AIDS.

Our analyses have also indicated higher T-bet expression in splenic Tfh cells at the chronic phase indicating the accumulation of Th1-like Tfh cells (16) (Figures 1B and 2). Interestingly, from these initial observations the list of pathogens impacting on Tfh function and differentiation leading to abortive differentiation is growing (63-66). Although T-bet has been reported to antagonize the expression of IL-21 $(67,68)$, IL-21 mRNA expression in sorted splenic Tfh cells of chronically SIV-infected RMs is not lower as compared to splenic Tfh cells isolated from healthy monkeys. The depletion Tfh cells may participate in the decrease of IL-21 that has been reported in HIV-infected individuals $(69,70)$. Such observation is of crucial importance, given the known role of IL-21 in controlling chronic viral infections by supporting CD8 T cell function (71-73). Schultz et al. (74) proposed that expression of IL-21 can be a surrogate marker for Tfh cells that can be used in various clinical settings as a useful monitoring tool for immune-based interventions aimed at selectively boosting Tfh cell function in humans (74). However, this should be extremely limitative in the sense that IL-21 would be therefore enough to mimic Tfh cell function, not integrating the role of cell-cell contact interaction and the architecture of lymphoid organs. 


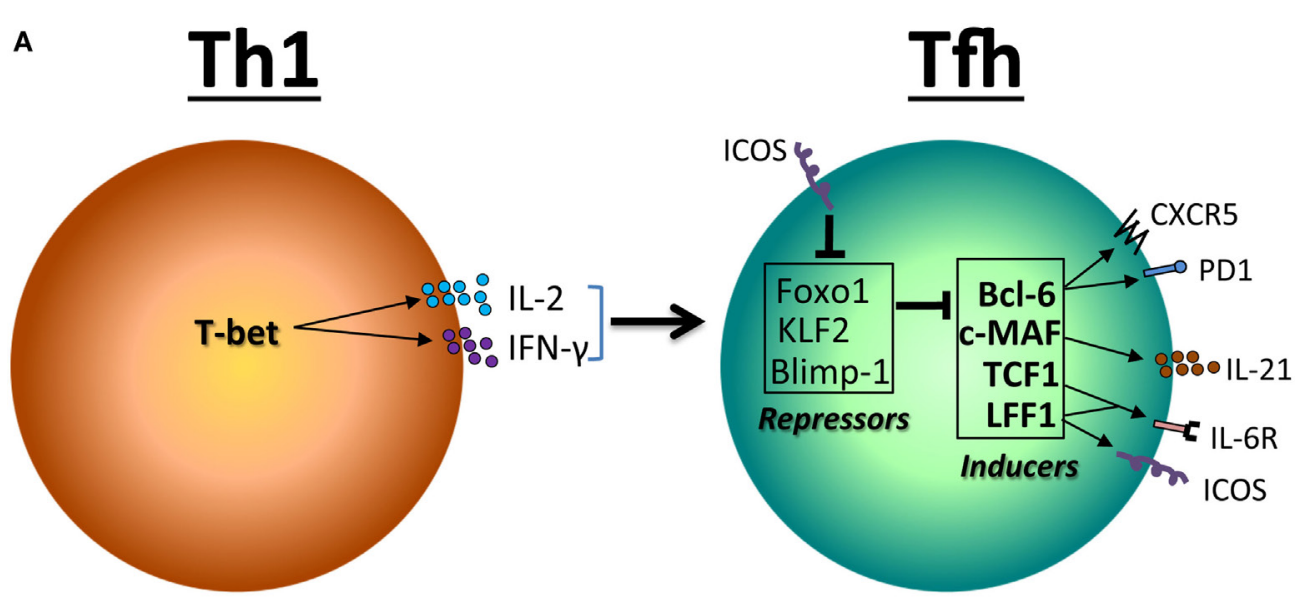

B

\section{Th1-like Tfh}

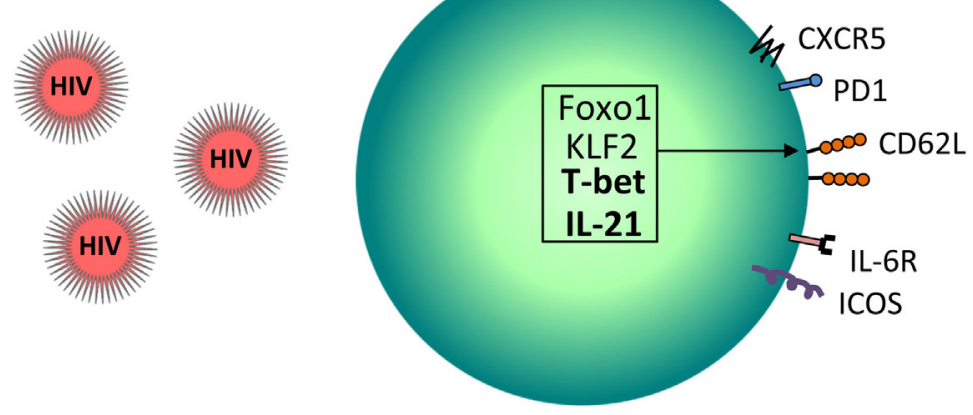

FIGURE 1 | Reciprocal expression of transcriptional factors in Th1 and follicular T helper (Tfh) cells. (A) T-bet is the principal transcription factor for the differentiation and function of Th1 CD4 T cell. T-bet inhibits the expression of programmed death molecule-1 (PD-1) but induces IL-2 and IFN- $\gamma$, which in turn leads to the expression of Foxo1 and Krüppel-like factor 2 (KLF2). These factors including Blimp-1 inhibit Bcl-6, c-MAF, TCF1, and LEF1 necessary for the differentiation and function of Tfh cells. (B) In the context of HIV/SIV infection, a Th1-like Tfh profile is associated with the expression of T-bet.

\section{Tfh CELLS AND B CELL IMMUNITY DURING AIDS}

Besides CXCR5 and high levels of PD-1, Tfh cells express the inducible T-cell costimulator (ICOS) and CD40L $(57,75)$. Thus, Tfh cells provide survival and proliferation signals to B cells via CD40L, ICOS, IL-21, and BATF, which compete with deathinducing Fas-FasL interactions (76-78). IL-21 production by Tfh cells is an important mediator in most processes occurring inside germinal centers (GCs), namely, affinity maturation, classswitching, and differentiation of long-lived plasmacytoid cells. The depletion of Tfh cells in the spleen very early after infection may participate in the absence of maturation and loss of memory B cells (79-81). We found a positive correlation between B cell differentiation and Tfh cell number in the spleen of SIV-infected RMs (16), but no correlation between the extent of infection of Tfh cells and the percentages of memory B cell subsets, suggesting that infection of Tfh cells is not directly associated with abnormal B cell differentiation (16). Cubas and colleagues have proposed that excessive and persistent triggering of $\mathrm{PD}-1$ on LN Tfh cells may affect their ability to provide adequate $B$ cell help (31). It is noteworthy that patients who are responders to a Flu vaccine display an expansion of circulating Tfh-like cells compared to non-responders (82), supporting a role of Tfh cells in maintaining the pool of long live memory B cells (36). It has been proposed in HIV-infected individuals that a subpopulation of peripheral blood memory PD $-1^{+} \mathrm{CXCR} 5^{+} \mathrm{CD} 4^{+} \mathrm{T}$ cells is associated with the development of broadly neutralizing antibodies (bnAbs) (83). In the sera, higher level of CXCL13, the CXCR5 ligand, is associated with the detection of bnAbspositive in HIV-infected individuals (84). They propose that individuals able to generate HIV bnAbs may have superior GC responses (84). On the contrary, defect in Tfh cells can be associated with hypergammaglobulinemia and the absence of bnAbs. Therefore, the early depletion of Tfh cells in the spleen of SIV-infected monkeys may contribute to the absence of efficient B cell immune response in controlling HIV and SIV infections. The significant association between frequency and 


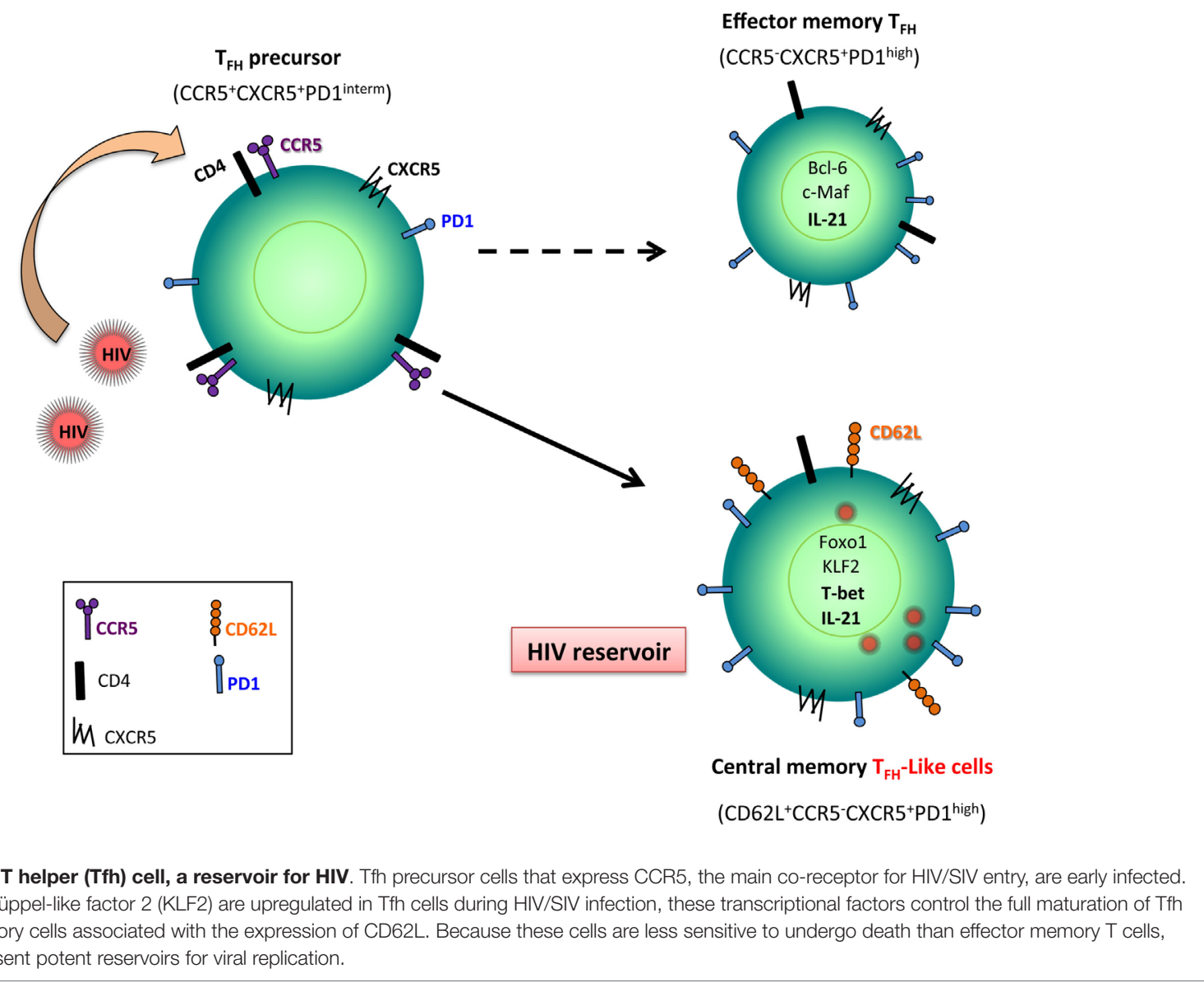

quality (IFN- $\gamma^{\text {low IL-2 }} 1^{\text {high }}$ ) of Env-specific Tfh cells and development of broad neutralization activity was recently described in NHP infected with SHIV virus (36). The co-evolution of virus (a process likely affected by the immunological pressure of the humoral responses too) and Tfh responses could represent major biological factors underlying the development of bnAbs. Investigation of the follicular immune reactions in lymph nodes from patients mounting bnAbs combined with studies utilizing the NHP model could provide critical information regarding the relative impact of these factors on this process.

Furthermore, several studies indicate that full expression of the Tfh differentiation program depends on cognate interactions between primed CD4 T cells and antigen-activated B cells (40, 85). Thus, a reciprocal regulation exists between Tfh and GC B cells, mediated by ICOS-ICOSL and CD40-CD40L interactions (86). In mice, the absence of PD-1 impairs Tfh function, resulting in suboptimal synthesis of important cytokines for the differentiation of long-lived plasma B cells (87). In SIV-infected RMs, B cell follicles and GCs become barely distinguishable in progressor animals, but are preserved in non-progressors, highlighting the profound remodeling of the normal splenic architecture that occurs during progression to AIDS (16). Tfh cells are hardly detectable on the B cell follicles of the spleen and LNs $(16,88,89)$.

Altogether, these observations showing abortive differentiation (quality) associated with the loss of Tfh cells (quantity) provides rationale for interventions aimed at boosting Tfh cell responses in the setting of HIV prevention or therapy, in particular for inducing the generation of more efficient antibodies and bnAbs.

\section{INFECTION OF Tfh CELLS}

Virus production in human immunodeficiency virus 1-infected individuals is largely the result of a dynamic process involving continuous rounds of de novo infection and replication in CD4 T cells with rapid turnover of both free virus and virus-producing cells. Thus, the level of viral load in the peripheral blood is a strong predictor of disease progression in pathogenic lentivirus infection (90-92). Earlier it has been clearly shown that even during clinical latency, HIV infection is never completely silent (93). Productively infected cells are detected at a higher frequency, emphasizing the progressive nature of HIV infection in lymphoid organs. Peripheral lymphoid tissues such as axillary and inguinal (LNs) and the spleen are major sites for HIV/SIV replication. An increasing body of evidence suggests that reservoirs, cell types or anatomical sites ("sanctuaries"), represent a major barrier to virus eradication (94). This has been recently demonstrated by the observation that despite intense ART therapy introduced early after infection, drug regimen has been unable to clear reservoirs (95). In this context, intestine tissues and their draining LNs also represent likely sanctuaries for persistent viral replication 
due to the particularity of the immune response in these sites, which are exposed to myriad of antigens to surveil the intestinal microbiome (96).

In the context of natural infection, it was clearly established that productively infected cells and virus trapped at the follicular dendritic cell (FDC) surface, showing a diffuse labeling over the FDC network in GC, are detectable in lymphoid tissues. The amount of viral particles trapped in the region of GCs increases with the pathogenicity $(97,98)$. Trapping of SIV in GCs is also observed in non-pathogenic SIV-infected African green monkeys (AGMs) (21) or in sooty mangabeys at the border of the GCs where Tfh cells are localized (99). During the early acute phase of infection, the viral dynamics in peripheral blood is quite similar between pathogenic and non-pathogenic lentiviral infections. However, a major distinction is evident by the end of the acute phase with higher numbers of SIV RNA ${ }^{+}$cells in RMs compared to AGMs, in which productively infected cells are barely detectable $(21,100)$. In HIV long-term non-progressors, it has been recently reported that $\mathrm{B}$ cell follicles represent an active site for viral replication (33), suggesting distinct viral dynamics. Furthermore, a clear difference in the dynamics of GC and B cells is observed between non-pathogenic (AGM) and pathogenic (RM) lentiviral infections. SIV-infected AGMs showed a more prominent B-cell activation than SIV-infected RMs, as manifested by the level of Ki67+ cells in the LN GCs at the set point compared to that in $\operatorname{RMs}(21,101,102)$. Altogether these observations indicated that the dynamic of GC and innate immunity is inversely correlated with viral replication and pathogenicity in peripheral LNs (100).

Growing evidences suggest that Tfh cells are infected by HIV/ SIV early after infection $(33,89,103-105)$. Splenic Tfh cells are infected early after SIV inoculation in RMs. Importantly, the frequencies and total numbers of SIV DNA ${ }^{+}$Tfh cells were higher at the chronic phase in non-progressor than in progressor RMs (16) suggesting that this population may be a latent pool associated with a "silent" Tfh phenotype in non-progressors. Consistent with in situ hybridization, few SIV p28 positive cells are observed in follicles of LN GCs of non-progressors (106).

Because Tfh cells do not express CCR5, the main co-receptor for HIV and SIV, how to explain that this memory subset is infected? Circulating Tfh cells are more permissive in vitro to HIV infection than non-Tfh cells (107). It has been reported that Tfh precursor cells (LN CXCR5 $5^{+} \mathrm{PD}-1^{\text {int }} \mathrm{CD} 4^{+}$) express CCR5 (106). This observation suggests that this subset $\left(\mathrm{PD}-1^{\text {int }} \mathrm{CD} 4^{+}\right)$ can be the target of infection and not Tfh themselves (Figure 2). Furthermore, the observation that Tfh cells display a $\mathrm{T}_{\mathrm{CM}}$ phenotype (16) may favor viral persistence because this CD4 T cell subset is less potent to die than $\mathrm{T}_{\mathrm{EM}} \mathrm{CD} 4 \mathrm{~T}$ cell subset. Our results have also demonstrated that despite their high frequency in SIV

\section{REFERENCES}

1. Sallusto F, Lenig D, Forster R, Lipp M, Lanzavecchia A. Two subsets of memory $\mathrm{T}$ lymphocytes with distinct homing potentials and effector functions. Nature (1999) 401:708-12. doi:10.1038/44385

2. Sallusto F, Geginat J, Lanzavecchia A. Central memory and effector memory T cell subsets: function, generation, and maintenance. Annu Rev Immunol (2004) 22:745-63. doi:10.1146/annurev.immunol.22.012703.104702
DNA, Tfh cells of non-progressors showed a similar or lower level of cellular SIV RNA compared to progressors (16), pointing to the fact that non-progressor Tfh cells might be less active to replicate SIV than Tfh cells of progressors, which might be related to the differentiation stage of Tfh cells (central versus $\mathrm{T}_{\mathrm{EM}}$ subset). Interestingly, HIV long terminal repeat contains binding sites for Bcl-6 that has previously been reported to repress HIV transcription (108), which may control HIV replication in Tfh cells.

Altogether these results indicate that Tfh cells may represent a potent viral reservoir in lymphoid tissues, in particular in non-progressors.

\section{CONCLUSION}

Although this review synthesizes recent advances on the role of Tfh cells in the context of HIV/SIV infections, several key questions remain to be addressed. By which mechanisms Tfh are early lost? Which are the processes leading to abortive Tfh cell differentiation by inducing a Th1-like profile? Does preventing CD4 $\mathrm{T}$ cell depletion boost the generation of high affinity and HIV-neutralizing Abs? Does ART therapy improve the quality and the quantity of splenic Tfh cells? Therefore, understanding the biology and dynamics of Tfh cells in deep tissues is of crucial interest for the development of novel vaccine strategies and the delineation of the cellular and molecular mechanisms leading to the formation of persistent reservoirs for HIV.

\section{AUTHOR CONTRIBUTIONS}

FM, VR, YF, HR, CB, BK, GA, RS, CP, ML, and JE contributed to writing of this review.

\section{FUNDING}

This work was supported by grants to JE from the Agence Nationale de Recherches sur le Sida et les Hépatites Virales (ANRS) and from The Canadian HIV Cure Enterprise Team Grant HIG-13305 from the Canadian Institutes of Health Research (CIHR) in partnership with CANFAR and IAS FM is supported by a fellowship from Fondation du CHU de Québec. CB and YF are supported by fellowships from ANRS. JE acknowledges the support of the Canada Research Chair program. RS is supported by FCT-Fundaçao para a Ciência e a Tecnologia/MEC-Ministério da Educaçao e Ciência através de fundos nacionais e quando aplicavel cofinanciado pelo FEDER, no âmbito do Acordo de Parceria PT2020 referente à unidade de investigaçao $n^{\circ} 4293$. RS is supported by the Fundaçao para a Ciência e a Tecnologia (FCT) (IF/00021/2014).

3. Zhou L, Chong MM, Littman DR. Plasticity of CD4+ T cell lineage differentiation. Immunity (2009) 30:646-55. doi:10.1016/j.immuni.2009. 05.001

4. Butcher EC, Picker LJ. Lymphocyte homing and homeostasis. Science (1996) 272:60-6. doi:10.1126/science.272.5258.60

5. Bromley SK, Mempel TR, Luster AD. Orchestrating the orchestrators: chemokines in control of T cell traffic. Nat Immunol (2008) 9:970-80. doi:10.1038/ni.f.213 
6. Legler DF, Loetscher M, Roos RS, Clark-Lewis I, Baggiolini M, Moser B. B cell-attracting chemokine 1, a human CXC chemokine expressed in lymphoid tissues, selectively attracts B lymphocytes via BLR1/CXCR5. J Exp Med (1998) 187:655-60. doi:10.1084/jem.187.4.655

7. Gunn MD, Ngo VN, Ansel KM, Ekland EH, Cyster JG, Williams LT. A B-cell-homing chemokine made in lymphoid follicles activates Burkitt's lymphoma receptor-1. Nature (1998) 391:799-803. doi:10.1038/35876

8. Barella L, Loetscher M, Tobler A, Baggiolini M, Moser B. Sequence variation of a novel heptahelical leucocyte receptor through alternative transcript formation. Biochem J (1995) 309(Pt 3):773-9. doi:10.1042/bj3090773

9. Dobner T, Wolf I, Emrich T, Lipp M. Differentiation-specific expression of a novel G protein-coupled receptor from Burkitt's lymphoma. Eur J Immunol (1992) 22:2795-9. doi:10.1002/eji.1830221107

10. He J, Tsai LM, Leong YA, Hu X, Ma CS, Chevalier N, et al. Circulating precursor CCR7(lo)PD-1(hi) CXCR5(+) CD4(+) T cells indicate Tfh cell activity and promote antibody responses upon antigen reexposure. Immunity (2013) 39:770-81. doi:10.1016/j.immuni.2013.09.007

11. Morita R, Schmitt N, Bentebibel SE, Ranganathan R, Bourdery L, Zurawski G, et al. Human blood CXCR5(+)CD4(+) T cells are counterparts of T follicular cells and contain specific subsets that differentially support antibody secretion. Immunity (2011) 34:108-21. doi:10.1016/j.immuni.2011.01.009

12. Hale JS, Youngblood B, Latner DR, Mohammed AU, Ye L, Akondy RS, et al. Distinct memory CD4+ T cells with commitment to $\mathrm{T}$ follicular helper- and $\mathrm{T}$ helper 1-cell lineages are generated after acute viral infection. Immunity (2013) 38:805-17. doi:10.1016/j.immuni.2013.02.020

13. Boswell KL, Paris R, Boritz E, Ambrozak D, Yamamoto T, Darko S, et al. Loss of circulating CD4 T cells with B cell helper function during chronic HIV infection. PLoS Pathog (2014) 10:e1003853. doi:10.1371/journal. ppat. 1003853

14. Ansel KM, McHeyzer-Williams LJ, Ngo VN, McHeyzer-Williams MG, Cyster JG. In vivo-activated CD4 $\mathrm{T}$ cells upregulate CXC chemokine receptor 5 and reprogram their response to lymphoid chemokines. J Exp Med (1999) 190:1123-34. doi:10.1084/jem.190.8.1123

15. Kim CH, Rott LS, Clark-Lewis I, Campbell DJ, Wu L, Butcher EC. Subspecialization of CXCR5+ T cells: B helper activity is focused in a germinal center-localized subset of CXCR5+ T cells. J Exp Med (2001) 193:1373-81. doi:10.1084/jem.193.12.1373

16. Moukambi F, Rabezanahary H, Rodrigues V, Racine G, Robitaille L, Krust B, et al. Early loss of splenic Tfh cells in SIV-infected rhesus macaques. PLoS Pathog (2015) 11:e1005287. doi:10.1371/journal.ppat.1005287

17. Ameisen JC, Estaquier J, Idziorek T, De Bels F. The relevance of apoptosis to AIDS pathogenesis. Trends Cell Biol (1995) 5:27-32. doi:10.1016/ S0962-8924(00)88933-3

18. Hurtrel B, Petit F, Arnoult D, Muller-Trutwin M, Silvestri G, Estaquier J. Apoptosis in SIV infection. Cell Death Differ (2005) 12(Suppl 1):979-90. doi:10.1038/sj.cdd. 4401600

19. Estaquier J, Idziorek T, de Bels F, Barre-Sinoussi F, Hurtrel B, Aubertin AM, et al. Programmed cell death and AIDS: significance of T-cell apoptosis in pathogenic and nonpathogenic primate lentiviral infections. Proc Natl Acad Sci U S A (1994) 91:9431-5. doi:10.1073/pnas.91.20.9431

20. Silvestri G, Sodora DL, Koup RA, Paiardini M, O’Neil SP, McClure HM, et al. Nonpathogenic SIV infection of sooty mangabeys is characterized by limited bystander immunopathology despite chronic high-level viremia. Immunity (2003) 18:441-52. doi:10.1016/S1074-7613(03)00060-8

21. Cumont MC, Diop O, Vaslin B, Elbim C, Viollet L, Monceaux V, et al. Early divergence in lymphoid tissue apoptosis between pathogenic and nonpathogenic simian immunodeficiency virus infections of nonhuman primates. J Virol (2008) 82:1175-84. doi:10.1128/JVI.00450-07

22. Monceaux V, Estaquier J, Fevrier M, Cumont MC, Riviere Y, Aubertin AM, et al. Extensive apoptosis in lymphoid organs during primary SIV infection predicts rapid progression towards AIDS. AIDS (2003) 17:1585-96. doi:10.1097/00002030-200307250-00002

23. Viollet L, Monceaux V, Petit F, Ho Tsong Fang R, Cumont MC, Hurtrel $\mathrm{B}$, et al. Death of $\mathrm{CD} 4+\mathrm{T}$ cells from lymph nodes during primary SIVmac251 infection predicts the rate of AIDS progression. J Immunol (2006) 177:6685-94. doi:10.4049/jimmunol.177.10.6685

24. Li Q, Duan L, Estes JD, Ma ZM, Rourke T, Wang Y, et al. Peak SIV replication in resting memory $\mathrm{CD} 4+\mathrm{T}$ cells depletes gut lamina propria $\mathrm{CD} 4+\mathrm{T}$ cells. Nature (2005) 434:1148-52. doi:10.1038/nature03513
25. Mattapallil JJ, Douek DC, Hill B, Nishimura Y, Martin M, Roederer M. Massive infection and loss of memory CD4+ $\mathrm{T}$ cells in multiple tissues during acute SIV infection. Nature (2005) 434:1093-7. doi:10.1038/ nature 03501

26. Picker LJ, Hagen SI, Lum R, Reed-Inderbitzin EF, Daly LM, Sylwester AW, et al. Insufficient production and tissue delivery of CD4+ memory $\mathrm{T}$ cells in rapidly progressive simian immunodeficiency virus infection. J Exp Med (2004) 200:1299-314. doi:10.1084/jem.20041049

27. Veazey RS, Tham IC, Mansfield KG, DeMaria M, Forand AE, Shvetz DE, et al. Identifying the target cell in primary simian immunodeficiency virus (SIV) infection: highly activated memory $\mathrm{CD} 4(+) \mathrm{T}$ cells are rapidly eliminated in early SIV infection in vivo. J Virol (2000) 74:57-64. doi:10.1128/ JVI.74.1.57-64.2000

28. Arnoult D, Petit F, Lelievre JD, Lecossier D, Hance A, Monceaux V, et al. Caspase-dependent and -independent T-cell death pathways in pathogenic simian immunodeficiency virus infection: relationship to disease progression. Cell Death Differ (2003) 10:1240-52. doi:10.1038/sj.cdd.4401289

29. Yue FY, Lo C, Sakhdari A, Lee EY, Kovacs CM, Benko E, et al. HIV-specific IL-21 producing CD4+ T cells are induced in acute and chronic progressive HIV infection and are associated with relative viral control. J Immunol (2010) 185:498-506. doi:10.4049/jimmunol.0903915

30. Lindqvist M, van Lunzen J, Soghoian DZ, Kuhl BD, Ranasinghe S, Kranias $\mathrm{G}$, et al. Expansion of HIV-specific T follicular helper cells in chronic HIV infection. J Clin Invest (2012) 122:3271-80. doi:10.1172/JCI64314

31. Cubas RA, Mudd JC, Savoye AL, Perreau M, van Grevenynghe J, Metcalf $\mathrm{T}$, et al. Inadequate $\mathrm{T}$ follicular cell help impairs $\mathrm{B}$ cell immunity during HIV infection. Nat Med (2013) 19:494-9. doi:10.1038/nm.3109

32. Brenchley JM, Vinton C, Tabb B, Hao XP, Connick E, Paiardini M, et al. Differential infection patterns of CD4+ T cells and lymphoid tissue viral burden distinguish progressive and nonprogressive lentiviral infections. Blood (2012) 120:4172-81. doi:10.1182/blood-2012-06-437608

33. Fukazawa Y, Lum R, Okoye AA, Park H, Matsuda K, Bae JY, et al. B cell follicle sanctuary permits persistent productive simian immunodeficiency virus infection in elite controllers. Nat Med (2015) 21:132-9. doi:10.1038/ nm.3781

34. Petrovas C, Yamamoto T, Gerner MY, Boswell KL, Wloka K, Smith EC, et al. CD4 T follicular helper cell dynamics during SIV infection. J Clin Invest (2012) 122:3281-94. doi:10.1172/JCI63039

35. Xu H, Wang X, Malam N, Lackner AA, Veazey RS. Persistent simian immunodeficiency virus infection causes ultimate depletion of follicular Th cells in AIDS. J Immunol (2015) 195:4351-7. doi:10.4049/jimmunol.1501273

36. Yamamoto T, Lynch RM, Gautam R, Matus-Nicodemos R, Schmidt SD, Boswell KL, et al. Quality and quantity of TFH cells are critical for broad antibody development in SHIVAD8 infection. Sci Transl Med (2015) 7:298ra120. doi:10.1126/scitranslmed.aab3964

37. Szabo SJ, Kim ST, Costa GL, Zhang X, Fathman CG, Glimcher LH. A novel transcription factor, T-bet, directs Th1 lineage commitment. Cell (2000) 100:655-69. doi:10.1016/S0092-8674(00)80702-3

38. Ivanov II, McKenzie BS, Zhou L, Tadokoro CE, Lepelley A, Lafaille JJ, et al. The orphan nuclear receptor RORgammat directs the differentiation program of proinflammatory IL-17+ Thelper cells. Cell (2006) 126:1121-33. doi:10.1016/j.cell.2006.07.035

39. Zheng W, Flavell RA. The transcription factor GATA-3 is necessary and sufficient for Th2 cytokine gene expression in CD4 T cells. Cell (1997) 89:587-96. doi:10.1016/S0092-8674(00)80240-8

40. Johnston RJ, Poholek AC, DiToro D, Yusuf I, Eto D, Barnett B, et al. Bcl6 and Blimp-1 are reciprocal and antagonistic regulators of $\mathrm{T}$ follicular helper cell differentiation. Science (2009) 325:1006-10. doi:10.1126/science. 1175870

41. Nurieva RI, Chung Y, Martinez GJ, Yang XO, Tanaka S, Matskevitch TD, et al. Bcl6 mediates the development of $\mathrm{T}$ follicular helper cells. Science (2009) 325:1001-5. doi:10.1126/science.1176676

42. Yu D, Rao S, Tsai LM, Lee SK, He Y, Sutcliffe EL, et al. The transcriptional repressor Bcl-6 directs T follicular helper cell lineage commitment. Immunity (2009) 31:457-68. doi:10.1016/j.immuni.2009.07.002

43. Eddahri F, Denanglaire S, Bureau F, Spolski R, Leonard WJ, Leo O, et al. Interleukin-6/STAT3 signaling regulates the ability of naive $\mathrm{T}$ cells to acquire B-cell help capacities. Blood (2009) 113:2426-33. doi:10.1182/ blood-2008-04-154682 
44. Bauquet AT, Jin H, Paterson AM, Mitsdoerffer M, Ho IC, Sharpe AH, et al. The costimulatory molecule ICOS regulates the expression of c-Maf and IL-21 in the development of follicular T helper cells and TH-17 cells. Nat Immunol (2009) 10:167-75. doi:10.1038/ni.1690

45. Kroenke MA, Eto D, Locci M, Cho M, Davidson T, Haddad EK, et al. Bcl6 and Maf cooperate to instruct human follicular helper CD4 T cell differentiation. J Immunol (2012) 188:3734-44. doi:10.4049/jimmunol.1103246

46. Lee JY, Skon CN, Lee YJ, Oh S, Taylor JJ, Malhotra D, et al. The transcription factor KLF2 restrains CD4(+) T follicular helper cell differentiation. Immunity (2015) 42:252-64. doi:10.1016/j.immuni.2015.01.013

47. Weber JP, Fuhrmann F, Feist RK, Lahmann A, Al Baz MS, Gentz LJ, et al. ICOS maintains the $\mathrm{T}$ follicular helper cell phenotype by down-regulating Kruppel-like factor 2. J Exp Med (2015) 212:217-33. doi:10.1084/ jem.20141432

48. Wang H, Geng J, Wen X, Bi E, Kossenkov AV, Wolf AI, et al. The transcription factor Foxp 1 is a critical negative regulator of the differentiation of follicular helper T cells. Nat Immunol (2014) 15:667-75. doi:10.1038/ni.2890

49. Xiao N, Eto D, Elly C, Peng G, Crotty S, Liu YC. The E3 ubiquitin ligase Itch is required for the differentiation of follicular helper T cells. Nat Immunol (2014) 15:657-66. doi:10.1038/ni.2912

50. Fabre S, Carrette F, Chen J, Lang V, Semichon M, Denoyelle C, et al. FOXO1 regulates L-selectin and a network of human $\mathrm{T}$ cell homing molecules downstream of phosphatidylinositol 3-kinase. J Immunol (2008) 181:2980-9. doi:10.4049/jimmunol.181.5.2980

51. Kerdiles YM, Beisner DR, Tinoco R, Dejean AS, Castrillon DH, DePinho RA, et al. Foxo1 links homing and survival of naive $\mathrm{T}$ cells by regulating L-selectin, CCR7 and interleukin 7 receptor. Nat Immunol (2009) 10:176-84. doi:10.1038/ni.1689

52. Estaquier J, Idziorek T, Zou W, Emilie D, Farber CM, Bourez JM, et al. T helper type 1/T helper type 2 cytokines and $\mathrm{T}$ cell death: preventive effect of interleukin 12 on activation-induced and CD95 (FAS/APO-1)-mediated apoptosis of CD4+ T cells from human immunodeficiency virus-infected persons. J Exp Med (1995) 182:1759-67. doi:10.1084/jem.182.6.1759

53. Estaquier J, Tanaka M, Suda T, Nagata S, Golstein P, Ameisen JC. Fasmediated apoptosis of CD4+ and CD8+ T cells from human immunodeficiency virus-infected persons: differential in vitro preventive effect of cytokines and protease antagonists. Blood (1996) 87:4959-66.

54. Katsikis PD, Wunderlich ES, Smith CA, Herzenberg LA, Herzenberg LA. Fas antigen stimulation induces marked apoptosis of $\mathrm{T}$ lymphocytes in human immunodeficiency virus-infected individuals. J Exp Med (1995) 181:2029-36. doi:10.1084/jem.181.6.2029

55. Liu X, Chen X, Zhong B, Wang A, Wang X, Chu F, et al. Transcription factor achaete-scute homologue 2 initiates follicular T-helper-cell development. Nature (2014) 507:513-8. doi:10.1038/nature12910

56. Vaeth M, Muller G, Stauss D, Dietz L, Klein-Hessling S, Serfling E, et al. Follicular regulatory $\mathrm{T}$ cells control humoral autoimmunity via NFAT2regulated CXCR5 expression. J Exp Med (2014) 211:545-61. doi:10.1084/ jem.20130604

57. Crotty S. Follicular helper CD4 T cells (TFH). Annu Rev Immunol (2011) 29:621-63. doi:10.1146/annurev-immunol-031210-101400

58. Oestreich KJ, Mohn SE, Weinmann AS. Molecular mechanisms that control the expression and activity of Bcl-6 in TH1 cells to regulate flexibility with a TFH-like gene profile. Nat Immunol (2012) 13:405-11. doi:10.1038/ ni. 2242

59. Ballesteros-Tato A, Leon B, Graf BA, Moquin A, Adams PS, Lund FE, et al. Interleukin-2 inhibits germinal center formation by limiting $\mathrm{T}$ follicular helper cell differentiation. Immunity (2012) 36:847-56. doi:10.1016/j. immuni.2012.02.012

60. Nurieva RI, Podd A, Chen Y, Alekseev AM, Yu M, Qi X, et al. STAT5 protein negatively regulates $\mathrm{T}$ follicular helper (Tfh) cell generation and function. J Biol Chem (2012) 287:11234-9. doi:10.1074/jbc.M111. 324046

61. Johnston RJ, Choi YS, Diamond JA, Yang JA, Crotty S. STAT5 is a potent negative regulator of TFH cell differentiation. J Exp Med (2012) 209:243-50. doi:10.1084/jem.20111174

62. Yamashita K, Kawata K, Matsumiya H, Kamekura R, Jitsukawa S, Nagaya T, et al. Bob1 limits cellular frequency of T-follicular helper cells. Eur J Immunol (2016) 46:1361-70. doi:10.1002/eji.201545499
63. Pepper M, Pagan AJ, Igyarto BZ, Taylor JJ, Jenkins MK. Opposing signals from the Bcl6 transcription factor and the interleukin-2 receptor generate T helper 1 central and effector memory cells. Immunity (2011) 35:583-95. doi:10.1016/j.immuni.2011.09.009

64. Nakayamada S, Kanno Y, Takahashi H, Jankovic D, Lu KT, Johnson TA, et al. Early Th1 cell differentiation is marked by a Tfh cell-like transition. Immunity (2011) 35:919-31. doi:10.1016/j.immuni.2011.11.012

65. Rodrigues V, Laforge M, Campillo-Gimenez L, Soundaramourty C, Correia-de-Oliveira A, Dinis-Oliveira RJ, et al. Abortive T follicular helper development is associated with a defective humoral response in Leishmania infantum-infected macaques. PLoS Pathog (2014) 10:e1004096. doi:10.1371/ journal.ppat.1004096

66. Obeng-Adjei N, Portugal S, Tran TM, Yazew TB, Skinner J, Li S, et al. Circulating Th1-cell-type Th cells that exhibit impaired B Cell help are preferentially activated during acute malaria in children. Cell Rep (2015) 13:425-39. doi:10.1016/j.celrep.2015.09.004

67. Mehta DS, Wurster AL, Weinmann AS, Grusby MJ. NFATc2 and T-bet contribute to T-helper-cell-subset-specific regulation of IL-21 expression. Proc Natl Acad Sci U S A (2005) 102:2016-21. doi:10.1073/pnas.0409512102

68. Suto A, Kashiwakuma D, Kagami S, Hirose K, Watanabe N, Yokote K, et al. Development and characterization of IL-21-producing CD4+ T cells. J Exp Med (2008) 205:1369-79. doi:10.1084/jem.20072057

69. Iannello A, Boulassel MR, Samarani S, Debbeche O, Tremblay C, Toma E, et al. Dynamics and consequences of IL-21 production in HIV-infected individuals: a longitudinal and cross-sectional study. J Immunol (2010) 184:114-26. doi:10.4049/jimmunol.0901967

70. Bekele Y, Amu S, Bobosha K, Lantto R, Nilsson A, Endale B, et al. Impaired phenotype and function of $\mathrm{T}$ follicular helper cells in HIV-1-infected children receiving ART. Medicine (Baltimore) (2015) 94:e1125. doi:10.1097/ MD.0000000000001125

71. Elsaesser H, Sauer K, Brooks DG. IL-21 is required to control chronic viral infection. Science (2009) 324:1569-72. doi:10.1126/science.1174182

72. Frohlich A, Kisielow J, Schmitz I, Freigang S, Shamshiev AT, Weber J, et al. IL-21R on T cells is critical for sustained functionality and control of chronic viral infection. Science (2009) 324:1576-80. doi:10.1126/science. 1172815

73. Yi JS, Du M, Zajac AJ. A vital role for interleukin-21 in the control of a chronic viral infection. Science (2009) 324:1572-6. doi:10.1126/ science.1175194

74. Schultz BT, Teigler JE, Pissani F, Oster AF, Kranias G, Alter G, et al. Circulating HIV-specific interleukin-21(+)CD4(+) T cells represent peripheral Tfh cells with antigen-dependent helper functions. Immunity (2016) 44:167-78. doi:10.1016/j.immuni.2015.12.011

75. Ma CS, Deenick EK, Batten M, Tangye SG. The origins, function, and regulation of T follicular helper cells. J Exp Med (2012) 209:1241-53. doi:10.1084/jem.20120994

76. Nurieva RI, Chung Y, Hwang D, Yang XO, Kang HS, Ma L, et al. Generation of $\mathrm{T}$ follicular helper cells is mediated by interleukin-21 but independent of T helper 1, 2, or 17 cell lineages. Immunity (2008) 29:138-49. doi:10.1016/j. immuni.2008.07.010

77. Linterman MA, Beaton L, Yu D, Ramiscal RR, Srivastava M, Hogan JJ, et al. IL-21 acts directly on B cells to regulate Bcl-6 expression and germinal center responses. J Exp Med (2010) 207:353-63. doi:10.1084/jem.20091738

78. Zotos D, Coquet JM, Zhang Y, Light A, D'Costa K, Kallies A, et al. IL-21 regulates germinal center $\mathrm{B}$ cell differentiation and proliferation through a B cell-intrinsic mechanism. J Exp Med (2010) 207:365-78. doi:10.1084/ jem.20091777

79. Moir S, Fauci AS. B cells in HIV infection and disease. Nat Rev Immunol (2009) 9:235-45. doi:10.1038/nri2524

80. Moir S, Malaspina A, Pickeral OK, Donoghue ET, Vasquez J, Miller NJ, et al. Decreased survival of B cells of HIV-viremic patients mediated by altered expression of receptors of the TNF superfamily. J Exp Med (2004) 200:587-99. doi:10.1084/jem.20032236

81. Kuhrt D, Faith SA, Leone A, Rohankedkar M, Sodora DL, Picker LJ, et al. Evidence of early B-cell dysregulation in simian immunodeficiency virus infection: rapid depletion of naive and memory B-cell subsets with delayed reconstitution of the naive B-cell population. J Virol (2010) 84:2466-76. doi:10.1128/JVI.01966-09 
82. Pallikkuth S, Parmigiani A, Silva SY, George VK, Fischl M, Pahwa R, et al. Impaired peripheral blood T-follicular helper cell function in HIV-infected nonresponders to the $2009 \mathrm{H} 1 \mathrm{N1} / 09$ vaccine. Blood (2012) 120:985-93. doi:10.1182/blood-2011-12-396648

83. Locci M, Havenar-Daughton C, Landais E, Wu J, Kroenke MA, Arlehamn CL, et al. Human circulating PD-1+CXCR3-CXCR5+ memory Tfh cells are highly functional and correlate with broadly neutralizing HIV antibody responses. Immunity (2013) 39:758-69. doi:10.1016/j.immuni.2013.08.031

84. Havenar-Daughton C, Lindqvist M, Heit A, Wu JE, Reiss SM, Kendric K, et al. CXCL13 is a plasma biomarker of germinal center activity. Proc Natl Acad Sci U S A (2016) 113:2702-7. doi:10.1073/pnas.1520112113

85. Kerfoot SM, Yaari G, Patel JR, Johnson KL, Gonzalez DG, Kleinstein SH, et al. Germinal center B cell and T follicular helper cell development initiates in the interfollicular zone. Immunity (2011) 34:947-60. doi:10.1016/j. immuni.2011.03.024

86. Baumjohann D, Preite S, Reboldi A, Ronchi F, Ansel KM, Lanzavecchia A, et al. Persistent antigen and germinal center B cells sustain T follicular helper cell responses and phenotype. Immunity (2013) 38:596-605. doi:10.1016/j. immuni.2012.11.020

87. Good-Jacobson KL, Szumilas CG, Chen L, Sharpe AH, Tomayko MM, Shlomchik MJ. PD-1 regulates germinal center B cell survival and the formation and affinity of long-lived plasma cells. Nat Immunol (2010) 11:535-42. doi:10.1038/ni.1877

88. Hong JJ, Amancha PK, Rogers K, Ansari AA, Villinger F. Spatial alterations between $\mathrm{CD} 4(+) \mathrm{T}$ follicular helper, $\mathrm{B}$, and $\mathrm{CD} 8(+) \mathrm{T}$ cells during simian immunodeficiency virus infection: T/B cell homeostasis, activation, and potential mechanism for viral escape. J Immunol (2012) 188:3247-56. doi:10.4049/jimmunol.1103138

89. Xu Y, Weatherall C, Bailey M, Alcantara S, De Rose R, Estaquier J, et al. Simian immunodeficiency virus infects follicular helper CD4 T cells in lymphoid tissues during pathogenic infection of pigtail macaques. $J$ Virol (2013) 87:3760-73. doi:10.1128/JVI.02497-12

90. Lifson JD, Nowak MA, Goldstein S, Rossio JL, Kinter A, Vasquez G, et al. The extent of early viral replication is a critical determinant of the natural history of simian immunodeficiency virus infection. J Virol (1997) 71:9508-14.

91. Mellors JW, Rinaldo CR Jr, Gupta P, White RM, Todd JA, Kingsley LA. Prognosis in HIV-1 infection predicted by the quantity of virus in plasma. Science (1996) 272:1167-70. doi:10.1126/science.272.5265.1167

92. Watson A, Ranchalis J, Travis B, McClure J, Sutton W, Johnson PR, et al. Plasma viremia in macaques infected with simian immunodeficiency virus: plasma viral load early in infection predicts survival. J Virol (1997) 71:284-90.

93. Pantaleo G, Graziosi C, Demarest JF, Butini L, Montroni M, Fox CH, et al. HIV infection is active and progressive in lymphoid tissue during the clinically latent stage of disease. Nature (1993) 362:355-8. doi:10.1038/362355a0

94. Blankson JN, Persaud D, Siliciano RF. The challenge of viral reservoirs in HIV-1 infection. Annu Rev Med (2002) 53:557-93. doi:10.1146/annurev. med.53.082901.104024

95. Whitney JB, Hill AL, Sanisetty S, Penaloza-MacMaster P, Liu J, Shetty M, et al. Rapid seeding of the viral reservoir prior to SIV viraemia in rhesus monkeys. Nature (2014) 512:74-7. doi:10.1038/nature13594

96. Cumont MC, Monceaux V, Viollet L, Lay S, Parker R, Hurtrel B, et al. TGF-beta in intestinal lymphoid organs contributes to the death of armed effector CD8 T cells and is associated with the absence of virus containment in Rhesus macaques infected with the simian immunodeficiency virus. Cell Death Differ (2007) 14:1747-58. doi:10.1038/sj.cdd.4402192

97. Chakrabarti L, Cumont MC, Montagnier L, Hurtrel B. Variable course of primary simian immunodeficiency virus infection in lymph nodes: relation to disease progression. J Virol (1994) 68:6634-43.
98. Chakrabarti L, Baptiste V, Khatissian E, Cumont MC, Aubertin AM, Montagnier L, et al. Limited viral spread and rapid immune response in lymph nodes of macaques inoculated with attenuated simian immunodeficiency virus. Virology (1995) 213:535-48. doi:10.1006/viro.1995.0026

99. Rey-Cuille MA, Berthier JL, Bomsel-Demontoy MC, Chaduc Y, Montagnier L, Hovanessian AG, et al. Simian immunodeficiency virus replicates to high levels in sooty mangabeys without inducing disease. J Virol (1998) 72:3872-86

100. Campillo-Gimenez L, Laforge M, Fay M, Brussel A, Cumont MC, Monceaux $\mathrm{V}$, et al. Nonpathogenesis of simian immunodeficiency virus infection is associated with reduced inflammation and recruitment of plasmacytoid dendritic cells to lymph nodes, not to lack of an interferon type I response, during the acute phase. J Virol (2010) 84:1838-46. doi:10.1128/JVI.01496-09

101. Goldstein S, Brown CR, Ourmanov I, Pandrea I, Buckler-White A, Erb $\mathrm{C}$, et al. Comparison of simian immunodeficiency virus SIVagmVer replication and CD4+ T-cell dynamics in vervet and sabaeus African green monkeys. J Virol (2006) 80:4868-77. doi:10.1128/JVI.80.10.48684877.2006

102. Pandrea I, Apetrei C, Dufour J, Dillon N, Barbercheck J, Metzger M, et al. Simian immunodeficiency virus SIVagm.sab infection of Caribbean African green monkeys: a new model for the study of SIV pathogenesis in natural hosts. J Virol (2006) 80:4858-67. doi:10.1128/JVI.80.10.4858-4867. 2006

103. Perreau M, Savoye AL, De Crignis E, Corpataux JM, Cubas R, Haddad EK, et al. Follicular helper T cells serve as the major CD4 T cell compartment for HIV-1 infection, replication, and production. J Exp Med (2013) 210:143-56. doi:10.1084/jem.20121932

104. Kohler SL, Pham MN, Folkvord JM, Arends T, Miller SM, Miles B, et al. Germinal center $\mathrm{T}$ follicular helper cells are highly permissive to HIV-1 and alter their phenotype during virus replication. J Immunol (2016) 196:2711-22. doi:10.4049/jimmunol.1502174

105. Boritz EA, Darko S, Swaszek L, Wolf G, Wells D, Wu X, et al. Multiple origins of virus persistence during natural control of HIV infection. Cell (2016) 166(4):1004-15. doi:10.1016/j.cell.2016.06.039

106. Xu H, Wang X, Malam N, Aye PP, Alvarez X, Lackner AA, et al. Persistent simian immunodeficiency virus infection drives differentiation, aberrant accumulation, and latent infection of germinal center follicular $\mathrm{T}$ helper cells. J Virol (2015) 90:1578-87. doi:10.1128/JVI.02471-15

107. Pallikkuth S, Sharkey M, Babic DZ, Gupta S, Stone GW, Fischl MA, et al. Peripheral $\mathrm{T}$ follicular helper cells are the major HIV reservoir within central memory CD4 T cells in peripheral blood from chronically HIVinfected individuals on combination antiretroviral therapy. J Virol (2015) 90:2718-28. doi:10.1128/JVI.02883-15

108. Baron BW, Desai M, Baber LJ, Paras L, Zhang Q, Sadhu A, et al. BCL6 can repress transcription from the human immunodeficiency virus type I promoter/enhancer region. Genes Chromosomes Cancer (1997) 19:14-21. doi:10.1002/(SICI)1098-2264(199705)19:1<14::AID-GCC3>3.0.CO;2-3

Conflict of Interest Statement: The authors declare that the research was conducted in the absence of any commercial or financial relationships that could be construed as a potential conflict of interest.

Copyright (c) 2017 Moukambi, Rodrigues, Fortier, Rabezanahary, Borde, Krust, Andreani, Silvestre, Petrovas, Laforge and Estaquier. This is an open-access article distributed under the terms of the Creative Commons Attribution License (CC BY). The use, distribution or reproduction in other forums is permitted, provided the original author(s) or licensor are credited and that the original publication in this journal is cited, in accordance with accepted academic practice. No use, distribution or reproduction is permitted which does not comply with these terms. 